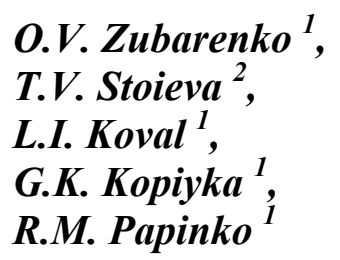

\section{PROGNOSIS OF CELLULAR ENERGY METABOLISM SHIFTS IN ADOLESCENTS WITH COMMUNITY-ACQUIRED PNEUMONIA}

Odesa National Medical University

Department of Pediatrics N 3 with postgraduate training ${ }^{1}$

Department of Pediatrics $N 2^{2}$

Valikhovsky Lane, 2, Odessa, 65000, Ukraine

Одеський національний медичний університет

кафедра педіатрії № 3 з післядипломною підготовкою ${ }^{1}$

(зав. - д. мед. н. О.В. Зубаренко)

кафедра педіатрії № $2^{2}$

(зав. - д. мед. н. Т.В. Стоєва)

Валіховський пров., 2, Одеса, 65000, Україна

e-mail:koval.larysa@ukr.net

\author{
Цитування: Медичні перспективи. 2021. Т. 26, № 1. С. 143-149 \\ Cited: Medicni perspektivi. 2021;26(1):143-149
}

Key words: community acquired pneumonia, children, cellular energy metabolism

Ключові слова: позалікарняна пневмонія, діти, клітинний енергетичний метаболізм

Ключевые слова: внебольничная пневмония, дети, клеточный энергетический метаболизм

\begin{abstract}
Prognosis of cellular energy metabolism shifts in adolescents with community-acquired pneumonia. Zubarenko O.V., Stoieva T.V., Koval L.I., Kopiyka G.K., Papinko R.M. Pneumonia is one of the most severe respiratory pathology forms in children, which contributes significantly to infant mortality. The high risk of chronic bronchopulmonary process and child's disability, in case of severe and complicated disease, requires careful pathophysiological change's analysis in community-acquired pneumonia (CAP) in children. In particular, for the prediction of these disorders in children with CAP are important the dysmetabolic phenomena study and the specific approaches development. The immediate aim of this work is to study the cellular energy metabolism (CEM) features and to develop approaches for the early bioenergetic disorders diagnostics in conditions of community-acquired pneumonia in adolescents. The aim of the study is to develop approaches for the early diagnosis of shifts in energy metabolism in children aged 14-18 years with CAP. An examination of 41 children aged 14-16 years with the definition of CEM indicators was conducted in order to develop an approach for predicting CEM disorders in communityacquired pneumonia using the method of logistic regression. A logistic regression method was used to develop a method for predicting CEM disorders in children with CAP. The characteristics of CEM in children with CAP were determined. A decrease in the succinate dehydrogenase activity and an increase in the lactate dehydrogenase / succinate dehydrogenase ratio in children with CAP relative to the reference parameters were observed, which indicated an inhibition of the anaerobic energy synthesis pathway. Two mathematical models for predicting CEM disorders in CAP based on logistic regression equations were proposed. The first mathematical model consisted of social and health characteristics and of pneumonia clinical course characteristics. In ROC analysis the area under the curve (AUC) was 0.82, diagnostic specificity - 71\%, diagnostic sensitivity - 90\%. The second model included only hematological parameters, AUC - 0.78, diagnostic specificity 69\%, diagnostic sensitivity - 81\%. Thus, changes in CEM in children with CAP aged 14 - 18 years have been established. Two methods for predicting disorders of CEM in children with CAP have been developed, which can be applied to optimize the treatment of children with CAP aged 14-18 years.
\end{abstract}

Реферат. Прогнозування зсувів у клітинному енергетичному метаболізмі при позалікарняній пневмонії в дітей підліткового віку. Зубаренко О.В., Стоєва Т.В., Коваль Л.І., Копійка Г.К., Папінко Р.М. Однією 3 найбільш тяжких форм респіраторної патологї в дітей є пневмонія, щзо вносить істотну частку в дитячу смертність. Високий ризик хронізації бронхолегеневого процесу й інвалідизації дитини, у випадку тяжкого та ускладненого перебігу захворювання, вимагають ретельного аналізу патофізіологічних змін при позалікарняній пневмонії (ПП) у дітей. Зокрема, на часі є вивчення дизметаболічних явищ та розробка специфічних підходів щчодо прогнозу розвитку таких розладів при ПП у дітей. Метою роботи є дослідження особливостей клітинно-енергетичного метаболізму (КЕМ) та розробка підходів до ранньої діагностики біоенергетичних порушень за умов позалікарняної пневмонії в дітей підліткового віку. Проведено обстеження 41 дитини віком 14-18 років із визначенням показників КЕМ, для розробки способу прогнозування розладів КЕМ при ПП було застосовано метод логістичної регресї. Визначено характеристики КЕМ у дітей, хворих на ПП. Конста- 
товано зниження активності сукцинатдегідрогенази та збільшення значення співвідношення лактатдегідрогенази до сукцинатдегідрогенази при ПП відносно показників контрольної групи, щчо вказувало на пригнічення анаеробного шляху метаболізму. Запропоновано дві математичні моделі прогнозування розладів КЕМ при ПП на базі рівняння логістичної регресії. Перша математична модель складалась з анамнестичних даних, супутніх патологічних станів та характеристик клінічного перебігу ПП, при RОС-аналізі площза під кривою (AUC) становила 0.82, діагностична специфічність - 71\%, діагностична чутливість - 90\%. Друга модель включала в себе гематологічні показники, AUC-0.78, діагностична специфічність - 69\%, діагностична чутливість - 81\%. Таким чином, установлено наявність зрушення КЕМ при ПП у дітей віком 14-18 років, розроблено два способи прогнозування розладів КЕМ при ПП у дітей, щсо може бути застосовано для вдосконалення медичнӧ̈ допомоги підліткам із урахуванням індивідуальних особливостей організму.

Pneumonia is a common and potentially dangerous disease in pediatric patients. The study of community-acquired pneumonia (CAP) in the last decade has allowed to improve understanding of this problem in many respects and to optimize diagnostic and therapeutic approaches.

In spite of modern achievements in medical science, the CAP incidence remains high, requiring a further in-depth study of the body state and the disease pathogenic mechanisms investigation. Taking into consideration the complexity of pathophysiological processes in pneumonia, the undeniable fact today is that the classical clinical examination is insufficient for the accurate disease severity assessment [9].

Numerous studies indicate that there is an association between shifts in metabolic profile and depth of tissue damage due to inflammatory stress. Thus, identifying cellular energy metabolism (CEM) shifts can improve understanding of the pneumonia underlying pathophysiological mechanisms in children and develop new tactics for the CAP prevention and treatment. The above noted is extremely important in conditions of increasing antibiotic resistance and slow development of effective and safe antibiotics, that can be used in pediatrics [8]. A comprehensive study of metabolism shifts in pneumonia in children identified a number of biomarkers - L-histidine, hypoxanthine, glutamic and uric-acids, L-tryptophan, L-carnitine and adenosine diphosphate, changes in the concentration of these substances in blood plasma and urine gave the best results in the likelihood of adverse pneumonia. It is crucial that the above-mentioned metabolites play an essential role in both the immune response and CEM, indicating a deep pathogenic link between the immune system and bioenergy [7, 11, 12, 14]. The study of enzymes intracellular activity of energy metabolism holds a special place in the characterization of CEM. Specifically, there is a close relationship between changes in succinate dehydrogenase (SDH) activity, lactate dehydrogenase (LDH), malate dehydrogenase, alpha-glycerophosphate dehydrogenase, and the CAP severity [2, $4,5]$. It is important to note that the methods of
CEM indicators assessment are characterized by high cost and complexity. In addition to that, modern bioethical principles require widespread implementation of noninvasive diagnostic approaches in medicine particularly in pediatrics.

Besides it should be noted that change in metabolism is essential for adolescent due to the influence of sex hormones, that cause special attention to these patients in the CEM disorders study [7].

The aim of the work is to study the CEM features and to develop approaches for the early diagnosis of bioenergetic disorders in conditions of communityacquired pneumonia in adolescents.

\section{MATERIALS AND METHODS OF RESEARCH}

We conducted a retrospective study, enrolling 41 children aged 14-18 with confirmed CAP, who were undergoing treatment in the pulmonology department of Odesa children's municipal hospital N 2. The study group had the following gender composition: boys - $23(56.10 \%)$, and girls - 18 (43.90\%). The enrollment was carried out in accordance to the inclusion/exclusion criteria. Inclusion criteria - radiologically confirmed pneumonia, CAP's nature. Exclusion criteria - concomitant chronic respiratory and heart diseases, immunodeficiency state. The control group, which included relatively healthy children was identical to the main group in age-sex structure and the total number of children namely 41 children, including boys $21(51.22 \%)$ and girls $-20(48.78 \%)$.

The design of the study involved three steps. The first step - a detailed study of patient's life history, medical history, general clinical examination, measurement of $\mathrm{Sa} \mathrm{O}_{2}$, determination of C-reactive protein (CRP) by a qualitative method, microbiological examination of sputum hematological indices calculation, namely neutrophil/lymphocyte ratio (NLR), leukocyte intoxication index (LII) of Kalf-Caliph [10]. Laboratory tests were performed when the child was admitted to the department (3-7 days from the disease onset).

The second stage of the work involved determining the CEM indices. We determined the intracellular LDH and SDH activity in peripheral blood lymphocytes. Enzyme activity was evaluated 
according to the Lloyd et al. method (1982) [3]. The $\mathrm{LDH} / \mathrm{SDH}$ ratio was used for integrated estimation of shifts in CEM [1].

At the final stage of the work, a mathematical model for the prediction of CEM was developed on the base of social and health characteristics of children with CAP. For that purpose data were processed by logistic regression [13]. Diagnostic accuracy of the mathematical model was assessed by the ROC analysis, curves (AUCs). Diagnostic specificity and diagnostic sensitivity of the mathematical model were also calculated.

In order to compare patient characteristics the type of distribution was determined and appropriate descriptive statistics methods were applied. We determined the arithmetic mean (M), the arithmetic mean error $(\mathrm{m})$, standard deviation ( $\underline{\sigma})$ and parametric Student test. A P value $<0.05$ was taken as the threshold for statistical significance. The statistical analyses were performed using GNU Project (2015) (GNU PSPP (Version 0.8.5) [Computer Software]. Free Software Foundation. Boston, MA).

The work was performed in accordance with the principles of the Helsinki Declaration of the World Medical Association "Ethical principles for medical research involving human subjects". Parents and official guardians of all children involved in the study gave written informed consent after they had been provided with full information about the purpose of the study, its methods and procedures.

\section{RESULTS AND DISCUSSION}

The study group of children with CAP had the following characteristics. The relevant etiological factor of CAP was identified only in 23 patients $56.10 \pm 7.75 \%$ according to the results of bacteriological examination. Among those cases in which the etiological factor was established, the gram-positive flora was definitely dominant $-73.91 \pm 9.36 \%$ $(p=0.008)$. Thus, in $60.87 \pm 10.41 \%$ cases, the etiological factor of the disease was Streptococcus pneumoniae, Staphylococcus pneumoniae was determined in $13.04 \pm 7.18 \%$ cases. The gramnegative flora was represented by Haemophilius influenza, which was diagnosed in $17.39 \pm 8.08 \%$ of patients. In addition, in $8.70 \pm 6.01 \%$, the atypical nature of CAP was ascertained, in particular, the presence of IgM to Chlamydia pneumoniae in the diagnostic titer (specific $\operatorname{IgM}>1: 16$ ) was determined.

Table 1 shows features of the medical and social history in the study group of adolescents with CAP. Table 2 describes the concomitant pathological conditions that require regular medical check-ups.

\section{Social and health anamnesis of children with CAP $(\mathbf{P} \pm m)$}

\begin{tabular}{|c|c|}
\hline Adverse factor & $\begin{array}{l}\text { Percentage of patients }(\%) \\
\qquad(\mathrm{n}=\mathbf{4 1})\end{array}$ \\
\hline Premature birth & $2.44 \pm 2.41$ \\
\hline Low birth weight & $4.88 \pm 3.32$ \\
\hline Early formula feeding, the first 4 months of life & $14.63 \pm 5.52$ \\
\hline Crowded place ( $>7$ persons per household) & $2.44 \pm 2.41$ \\
\hline Passive smoking & $31.71 \pm 7.27$ \\
\hline $\begin{array}{l}\text { Recurrent pneumoniae (at least two episodes of pneumonia } \\
\text { in one year or three episodes ever with intercritical radiographic } \\
\text { clearing of densities) }\end{array}$ & $4.88 \pm 3.32$ \\
\hline Recurrent respiratory tract infections & $9.76 \pm 4.63$ \\
\hline
\end{tabular}


As for the history of the present illness, the fever duration more than three days was in $53.66 \pm 7.76 \%$ of the surveyed, and the fever duration for at least three days at the time of hospitalization was registered in $21.95 \pm 6.46 \%(\mathrm{p}=0.002)$ cases, along with that in $24.39 \pm 6.71 \%$ of patients there was no fever at the pre-hospital stage $(\mathrm{p}=0.006)$. Fever above $39^{\circ} \mathrm{C}$ was found only in $12.20 \pm 5.11 \%$ of adolescents. The majority of patients were admitted to the hospital from $4^{\text {th }}$ to $7^{\text {th }}$ of the disease $60.98 \pm 7.62 \%$, hospitalization on the $3^{\text {rd }}$ day of the disease was recorded in $12.20 \pm 5.11 \%(\mathrm{p}=0.0014)$ of patients, and after the $7^{\text {th }}$ day - in $26.83 \pm 6.92 \%$ $(p<0.0001)$. Cough was recorded in the dominant number of the surveyed $-82.93 \pm 5.88 \%$ and in $17.07 \pm 5.88 \%$ of patients there was no such a complaint $(p<0,0001)$. Intoxication signs such as poor appetite and fatigue were observed in $56.10 \pm 7.75 \%$ of patients. Diagnostically significant decrease in the saturation level was documented in $26.83 \pm 6.92 \%$ of the surveyed children with CAP. Antibiotic therapy at the outpatient stage (within one week before CAP verification) was performed in $39.02 \pm 7.62 \%$ of patients with CAP.

Table 2

\section{Concomitant pathological conditions of children with community-acquired pneumonia $(\mathrm{P} \pm \mathrm{m})$}

\begin{tabular}{|c|c|}
\hline Concomitant pathological condition & $\begin{array}{l}\text { Percentage of patients (\%) } \\
\qquad(\mathrm{n}=41)\end{array}$ \\
\hline Chronic gastroduodenitis & $7.32 \pm 4.07$ \\
\hline $\begin{array}{l}\text { Functional gastrointestinal tract pathology (Functional disorder of } \\
\text { the biliary tract, irritable bowel syndrome, functional dyspepsia) }\end{array}$ & $26.83 \pm 6.92$ \\
\hline Chronic rhinosinusitis & $14.63 \pm 4.52$ \\
\hline Chronic adenoiditis & $2.44 \pm 2.41$ \\
\hline Chronic tonsillitis & $12.20 \pm 5.11$ \\
\hline Allergic rhinitis & $7.32 \pm 4.07$ \\
\hline Atopic eczema & $4.88 \pm 3.36$ \\
\hline Obesity & $7.32 \pm 4.07$ \\
\hline Thyroid insufficiency & $4.88 \pm 3.36$ \\
\hline Anemia & $7.32 \pm 4.07$ \\
\hline
\end{tabular}

Evaluation of the clinical and laboratory examination results showed that CAP in adolescents was with accompanied leukocytosis in $43.90 \pm 7.75 \%$

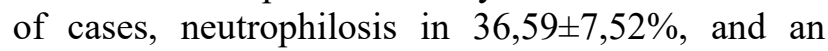
erythrocyte sedimentation rate (ESR) above $20 \mathrm{~mm} / \mathrm{h}$ - in $51.22 \pm 7.81 \%$ of cases. The hematologic indices calculation determined the NLR increase in a significant number of patients, namely
- in $70.73 \pm 7.11 \%$ of cases $(p=0.00018)$, a LII increase by Kalf-Caliph was established in $26.83 \pm 6.92 \%$ of cases and an absolute number of lymphocyte decrease - in $24.39 \pm 6.71 \%$. The increased C-reactive protein value was set in $48.78 \pm 7.81 \%$ of patients.

The morphological structure of CAP was characterized by the segmental type dominance, which 
was determined in $85.37 \pm 5.52 \%$ of patients, focal type was diagnosed in $14.63 \pm 5.52(\mathrm{p}<0.0001)$. Local pleural complications, in particular encysted pleurisy were recorded in $14.63 \pm 5.52 \%$ of the surveyed.

The study of CEM parameters revealed inhibition of the SDH activity $(2.01 \pm 0.085)$ C.U. in patients with CAP relative to the parameters of control group (2.74 \pm 0.066$)$ C.U. $(p<0.001)$, which indicated the presence of disorders in the Krebs cycle functioning. Along with that a significant increase in the average
LDH activity rate $(3.92 \pm 0.060)$ C.U. in children with CAP was not determined, compared with the average LDH activity rate in the control group $(4.11 \pm 0.081)$ C.U. $(p>0.05)$. It should be noted that there was an increase of the LDH/SDH index $(2.11 \pm 0.082)$ C.U. in adolescents with CAP, which indicated the inhibition of aerobic CEM processes and subsequent activation of anaerobic ones. The corresponding index in the control group was $(1.42 \pm 0.037)$ C.U. $(p<0.001)$ (Table 3).

\section{Enzyme activity of the lymphocytes in children with CAP $(M \pm m)$}

\begin{tabular}{|c|c|c|c|}
\hline $\mathrm{X}^{-}$ & $\begin{array}{c}\text { Control group } \\
n=41\end{array}$ & $\begin{array}{l}\text { Children with CAP } \\
\qquad n=41\end{array}$ & p - value \\
\hline SDH, C.U. & $2.74 \pm 0.066$ & $2.01 \pm 0.085$ & $<0.001$ \\
\hline LDH, C.U. & $4.11 \pm 0.081$ & $3.92 \pm 0.060$ & $>0.05$ \\
\hline LDH/SDH ratio, C.U. & $1.42 \pm 0.037$ & $2.11 \pm 0.082$ & $<0.001$ \\
\hline
\end{tabular}

Rates of enzyme activity and indices calculated on their basis (Table 3) were subjected to further statistical processing by logistic regression. Thus, diagnostic mathematical models were constructed for detecting children with CAP with impaired CEM. It was possible to build models with sufficient accuracy only in those cases when the LDH activity and the $\mathrm{LDH} / \mathrm{SDH}$ ratio were taken as a grouping attribute. The fact of CEM disorder was established in case of the CEM index excision the $\mathrm{M} \pm 2 \sigma$ interval of the corresponding indicator in the control group.

At the final stage of the study, coefficients were set for each of the explanatory signs, using the logistic regression method. The next step was to establish the best combination of logistic regression coefficients to ensure the highest quality of the mathematical model and to reduce the number of explanatory signs included in the equation. The total number of explanatory signs was 37 quantitative and qualitative characteristics of CAP, which were listed above and presented in Tables 1 and 2 .

For reliable differentiation of children with CAP with reduced SDH activity, and those with the decrease in SDH activity by more than $2 \sigma$, relative to the control group $-2.74 \pm 0.84$ C.U. $(\mathrm{M} \pm 2 \sigma)$, did not occur, the following logistic regression equation which contained 20 explanatory signs was built.

$$
y=0.003+b 1 \cdot x 1+\ldots+b 20 \cdot x 20
$$

where, $\mathrm{x}_{1}$ - female gender (yes-1/no-0), $\mathrm{b}_{1}-(-0.438) ; \mathrm{x}_{2}-$ passive smoking (yes-1/no-0), $\mathrm{b}_{2}-0.27 ; \mathrm{x}_{3}-$ chronic ENT pathology (yes-1/no$0), b_{3}-1.024 ; x_{4}-$ atopic dermatitis (yes- $1 /$ no- 0$), b_{4}-(-0.584) ; x_{5}-$ chronic gastroduodenitis (yes-1/no-0), $b_{5}-0.462 ; \mathrm{x}_{6}-$ obesity (yes-1/no$0), b_{6}-0.33 ; x_{7}-$ prematurity (yes- $1 /$ no -0$), b_{7}-(-0.129) ; x_{8}-$ illness duration before hospitalization (number of days), $\mathrm{b}_{8}-0.665 ; \mathrm{x}_{9}-$ fever duration at the pre-hospital stage (number of days), $b_{9}-0.684 ; x_{10}$ fever above $39^{\circ} \mathrm{C}$ (yes-1/no 0 ), $\mathrm{b}_{10}-0.059 ; \mathrm{x}_{11}$ - focal pneumonia (yes$1 /$ no 0$), b_{11}-0.8 ; x_{12}-$ complicated pneumonia (yes-1/no 0 ), $b_{12}-0.15$; $\mathrm{x}_{13}$ - absolute white blood cell count, $\mathrm{b}_{13}-0.4 ; \mathrm{x}_{14}$ - relative lymphocyte count, $b_{14}-(-0.301) ; x_{15}-$ relative mature neutrophils count, $b_{15}-(-$ $0.005) ; x_{16}-$ relative band neutrophil count, $b_{16}-0.329 ; x_{17}-E S R, b_{17}$ $(-0.17) ; \mathrm{x}_{18}-$ LII by Kalf-Caliph, $\mathrm{b}_{18}-(-0.899) ; \mathrm{x}_{19}-\mathrm{NLR}, \mathrm{b}_{19}-(-$ $0.094) ; \mathrm{x}_{20}$ - absolute lymphocyte count, $\mathrm{b}_{20}-0.164$.

The ROC analysis was applied to the obtained model, which established the following model characteristics: AUC -0.82 , which indicated the "very good" work of the mathematical model, diagnostic specificity $-71 \%$, diagnostic sensitivity $-90 \%$.

The following logistic regression equation separates groups of patients with $\mathrm{CAP}$ with a normal $\mathrm{LDH} / \mathrm{SDH}$ ratio and patients in whom this marker increased by more than $2 \sigma$, relative to the control group, which was $1.42 \pm 0.48$ C.U. $(\mathrm{M} \pm 2 \sigma)$. The mathematical model consisted of only 4 explanatory signs and corresponding coefficients:

$$
y=-0.061+b 1 \cdot x 1+\ldots+b 4 \cdot x 4
$$

where, $\mathrm{x}_{1}$ - relative lymphocyte count, $\mathrm{b}_{1}-(-0.117) ; \mathrm{x}_{2}$ - relative mature neutrophils count, $\mathrm{b}_{2}-0.048 ; \mathrm{x}_{3}-$ relative band neutrophils count, $\mathrm{b}_{3}$ $0.114 ; \mathrm{x}_{4}-\mathrm{NLR}, \mathrm{b}_{4}-0.036$

The area under the ROC curve was AUC - 0.78, which indicated the "good" mathematical model 
quality. The following operating characteristics of the mathematical model were determined: diagnostic specificity $-69 \%$, diagnostic sensitivity $-81 \%$.

Analysis of this study results showed that there are significant changes in CEM in adolescents with CAP, which manifest themselves in significant SDH reduction - a key enzyme of the Krebs cycle and in the LDH/SDH index increase, indicating a CEM shift toward anaerobic (less efficient) energy synthesis. Similar results were obtained in studies performed by other researchers but they identified more profound changes in CEM due to age differences of the examined children (average age 6 years) [2]. Similar changes in CEM were recorded by a group of authors in a study that included adult patients with complicated pneumonia [5].

Modern medical science cannot be limited to only high-precision clinical-laboratory methods, but it also requires progressive statistics for processing of the obtained data. This approach aims to create an informative and accessible way to detect changes in various disorders in children. Each of the given above mathematical models has certain advantages and disadvantages. The advantage of the first one is its high sensitivity and specificity in determining CEM disorders and the disadvantage is the large number of patient's characteristics that need to be evaluated. Regarding the second formula, it exhibits poorer sensitivity and specificity than the first formula but is relatively simple to calculate and includes only clinical blood counts and hematologic indices. The implementation of this study results significantly expands the diagnostic possibilities for the assessment of CEM and will allow separating the most vulnerable category of patients in order to prevent further chronization of acute inflammatory diseases, taking into account the individual characteristics of the organism.

Consequently, the focus of our study on the development of approaches for the noninvasive, accessible and cost-effective detection of changes in CEM in children with CAP is a feature of our work distinctive from other studies in this area.

Prospects for future research we see in the expansion of clinical groups for which this approach should be applied and in the methods development for the patients' differentiation according to the depth of CEM lesions in children with CAP, in order to identify the most vulnerable patients who should undergo a more detailed examination of their CEM, appropriate correction, and in some cases - counseling at the medical-genetic center.

\section{CONCLUSIONS}

1. In children with CAP aged 14-18 years changes in CEM, such as decreased SDH activity and elevation of the LDH /SDH ratio were found.

2. The comprehensive assessment of informativeness of clinical and anamnestic indicators and the cell-energy metabolism analysis results in CAP in adolescents was proved, this was confirmed by statistical methods and the effectiveness of the proposed mathematical models having significant diagnostic value. The developed models allow predicting the presence of changes in cellular energy metabolism, namely a decrease in LDH activity $(\mathrm{AUC}=0.82 ; \mathrm{Sp}=71 \% ; \mathrm{Se}=90 \%)$ and an increase in the $\mathrm{LDH} / \mathrm{SDH}$ index (AUC $=0.78 ; \mathrm{Sp}=69 \%$; $\mathrm{Se}=81 \%$ ) in the first days after the diagnosis of community-acquired pneumonia.

Conflict of interests. The authors declare no conflict of interest.

\section{REFERENCES}

1. Khunderyakova NV, Yachkula TV, Fedotcheva NI, Litvinova EG, Schwartsburd PM, Kondrashova MN, Zakharchenko MV, Plyasunova SA, Sukhorukov VS, Baranich TI. [A highly sensitive non-damaging method for detecting the mitochondria state by examining the blood lymphocytes smears of hte children with leukemia and myopathy compared to healthy children in order to detect significant differences]. Meditsinsky alfavit. 2017;20(2):27-30. Russian. doi: https://doi.org/10.33667/2078-5631

2. Li LA. [Application of metabolic energy therapy to correction energy deficit of immune cells in children with community-acquired pneumonia]. Byuleten fiziologii i patologii dykhaniya. 2015;57:35-41. Russian. doi: https://doi.org/10.12737/20122

3. Loyda Z, Gossrau R, Shibler TM. [Histochemistry of enzymes]. Moskva: Mir. 1982;272. Russian.
4. Nasibullin BA, Koval LI, Koretska HO. [Cytoenergetic status in children with community-acquired pneumonia]. Suchasna pediatriia. 2018;6(94):33-36. Ukranian. doi: https://doi.org/10.15574/SP.2018.93.33

5. Savchenko AA, Grinshteyn YuI, Dresvyankina LV, Aristov AI. [Chemiluminescent and enzymatic activity of blood neutrophils in patients with varying degrees of severity the community-acquired pneumonia]. Sibirskoe meditsinskoe obozrenie. 2015;5(95):55-61. Russian. doi: https://doi.org/10.20333/2500-0136

6. Cheng HL, Amatoury M, Steinbeck K. Energy expenditure and intake during puberty in healthy nonobese adolescents: a systematic review. Am J Clin Nutr. 2016 Oct;104(4):1061-74.

doi: https://doi.org/10.3945/ajcn.115.129205

7. Ambroggio L, Florin TA, Shah SS, Ruddy R, Yeomans L, Trexel J, Stringer KA. Emerging Biomarkers 
of Illness Severity: Urinary Metabolites Associated with Sepsis and Necrotizing Methicillin-Resistant Staphylococcus aureus Pneumonia. Pharmacotherapy. 2017 Sep;37(9):103342. doi: https://doi.org/10.1002/phar.1973

8. Zheng $\mathrm{Y}$, Ning $\mathrm{P}$, Luo Q, He Y, Yu X, Liu X, Chen Y, Wang X, Kang Y, Gao Z. Inflammatory responses relate to distinct bronchoalveolar lavage lipidome in community-acquired pneumonia patients: a pilot study. Respir Res. 2019 May 2;20(1):82.

doi: https://doi.org/10.1186/s12931-019-1028-8

9. Karakioulaki M, Stolz D. Biomarkers in Pneumonia-Beyond Procalcitonin. Int $\mathrm{J}$ Mol Sci. 2019 Apr 24;20(8):2004.

doi: https://doi.org/10.3390/ijms20082004

10. Korytko Z, Kulitka E, Chornenka H, Zachidnyy V. Use of integral hematological indices for diagnostics of athletes' adaptive processes. Journal of Physical Education and Sport. 2019 Jan;19(1):214-18. doi: https://doi.org/10.7752/jpes.2019.s1032
11. Ning P, Zheng Y, Luo Q, Liu X, Kang Y, Zhang Y, Zhang R, Xu Y, Yang D, Xi W, Wang K, Chen Y, An S, Gao Z. Metabolic profiles in communityacquired pneumonia: developing assessment tools for disease severity. Crit Care. 2018 May 14;22(1):130. doi: https://doi.org/10.1186/s13054-018-2049-2

12. Antcliffe D, Jiménez B, Veselkov K, Holmes E, Gordon AC. Metabolic Profiling in Patients with Pneumonia on Intensive Care. EBioMedicine. 2017 Apr;18:244-53. doi: https://doi.org/10.1016/j.ebiom.2017.03.034

13. Ranganathan P, Pramesh CS, Aggarwal R. Common pitfalls in statistical analysis: Logistic regression. Perspect Clin Res. 2017 Jul-Sep;8(3):148-51. doi: https://doi.org/10.4103/picr

14. Adamko DJ, Saude E, Bear M, Regush S, Robinson JL. Urine metabolomic profiling of children with respiratory tract infections in the emergency department: a pilot study. BMC Infect Dis. 2016 Aug 22;16(1):439. doi: https://doi.org/10.1186/s12879-016-1709-6

\section{СПИСОК ЛІТЕРАТУРИ}

1. Высокочувствительный неповреждающий способ выявления состояния митохондрий в организме путем их исследования внутри лимфоцитов крови на мазке выявление больших различий при лейкозах и миопатиях у больных детей по сравнению со здоровыми / Н. В. Хундерякова и др. Мед. алфавит. 2017. Т. 2, № 20 (317). С. 27-30. DOI: https://doi.org/10.33667/2078-5631

2. Ли Л. А. Применение метаболической энерготропной терапии для коррекции дефицита энергообеспечения иммунокомпетентных клеток у детей с внебольничной пневмонией. Бюл. физ. и nam. dblx. 2015. № 57. C. 35-41.

DOI: https://doi.org/10.12737/20122

3. Лойда 3., Госсрау Р., Шиблер Т.М. Гистохимия ферментов. Москва: Мир, 1982. 272 с.

4. Насібуллін Б. А., Коваль Л. І., Корецька Г. О. Цито-енергетичний статус у дітей при позалікарняній пневмонії. Сучасна педіатрія. 2018. Т. 94, № 6. С. 3336. DOI: https://doi.org/10.3945/ajen.115.129205

5. Савченко А. А., Гринштейн Ю. И., Дресвянкина Л. В., Аристов А. И. Хемилюминесцентная и ферментативная активность нейтрофилов крови у больных с разной степенью тяжести внебольничной пневмонии. Сибирское медицинское обозрение. 2015. T. 95, № 95. C. 55-61.

DOI: https://doi.org/10.20333/2500-0136

6. Cheng H. L., Amatoury M., Steinbeck K. Energy expenditure and intake during puberty in healthy nonobese adolescents: a systematic review. Am J Clin Nutr. 2016. Vol. 104, No.4. P. 1061-1074. DOI: https://doi.org/ 10.3945/ajcn.115.129205

7. Emerging Biomarkers of Illness Severity: Urinary Metabolites Associated with Sepsis and Necrotizing Methicillin-Resistant Staphylococcus aureus Pneumonia /
L. Ambroggio et al. Pharmacotherapy. 2017. Vol. 37, No. 9. P. 1033-1042.

DOI: https://doi.org/10.1002/phar.1973

8. Inflammatory responses relate to distinct bronchoalveolar lavage lipidome in community-acquired pneumoniapatients: a pilot study / Y. Zheng et al. RespirRes. 2019. Vol. 20, No. 1.

DOI: https://doi.org/10.1186/s12931-019-1028-8

9. Karakioulaki M., Stolz D. Biomarkers in Pneumonia-Beyond Procalcitonin. Int J Mol Sci. 2019. Vol. 20, No. 8.

DOI: https://doi.org/10.3390/ijms20082004

10. Korytko Z., Kulitka E., Chornenka H., Zachidnyy V. Use of integral hematological indices for diagnostics of athletes' adaptive processes. Journal of Physical Education and Sport. 2019. Vol. 19, No. 1. P. 214-218. DOI: https://doi.org/10.7752/jpes.2019.s1032

11. Metabolic profiles in community-acquired pneumonia: developing assessment tools for disease severity / P. Ning et al. Critical Care. 2018. Vol. 22. P. 130. DOI: https://doi.org/10.1186/s13054-018-2049-2

12. Metabolic Profiling in Patients with Pneumonia on Intensive Care / D. Antcliffe et al. EBioMedicine. 2017. Vol. 18. P. 244-253.

DOI: https://doi.org/10.1016/j.ebiom.2017.03.034

13. Ranganathan P., Pramesh C. S., Aggarwal R. Common pitfalls in statistical analysis: Logistic regression. Perspect Clin Res. 2017. Vol. 8, No. 3. P. 148-151. DOI: https://doi.org/10.4103/picr

14. Urine metabolomic profiling of children with respiratory tract infections in the emergency department: a pilot study / D. J. Adamko et al. BMC Infect Dis. 2016. Vol. 16, No. 1. P. 439.

DOI: https://doi.org/10.1186/s12879-016-1709-6 